
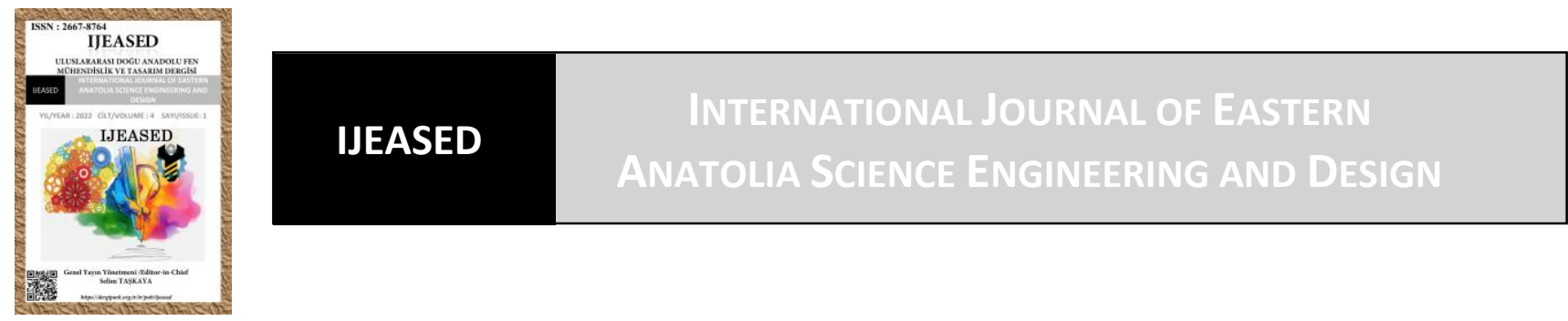

\author{
Uluslararası Doğu Anadolu Fen Mühendislik ve Tasarım Dergisi \\ ISSN: 2667-8764, 4(1), 53-66, 2022 \\ https://dergipark.org.tr/tr/pub/ijeased
}

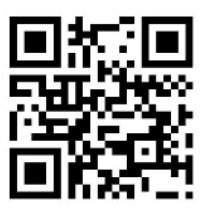

Derleme Makalesi / Review Article

Doi: $\underline{10.47898 / \text { ijeased.1031997 }}$

\title{
Futbol Sahalarında Hibrit Çim Kullanımının İrdelenmesi
}

\author{
Tuğrul HOCAOĞLU ${ }^{1}$, Bora BİNGÖL ${ }^{2 *}$
}

${ }^{1}$ Isparta Uygulamalı Bilimler Üniversitesi, Yalvaç MYO, Pazarlama ve Reklamcılık Bölümü, Isparta, 32400 , Türkiye.

${ }^{2}$ Burdur Mehmet Akif Ersoy Üniversitesi, Müh. Mimarlık Fakültesi, Peyzaj Mimarlığı Bölümü, Burdur, 15030, Türkiye.

\begin{tabular}{l|l|l}
\hline \multicolumn{1}{c|}{ Yazar Kimliği / Author ID (ORCID Number) } & \multicolumn{3}{|c}{ Makale Süreci / Article Process } \\
\hline "Sorumlu Yazar / Corresponding author : & Geliş Tarihi / Received Date : & 03.12 .2021 \\
bbingol@ @ehmetakif.edu.tr & Revizyon Tarihi / Revision Date : & 05.02 .2022 \\
\hline iD https://orcid.org/0000-0002-7096-3051, T. Hocaoğlu & Kabul Tarihi / Accepted Date : & 10.02 .2022 \\
iD https://orcid.org/0000-0001-9644-0921, B. Bingöl & Yayım Tarihi / Published Date : & 15.07 .2022 \\
\hline
\end{tabular}

Alıntı / Cite : Hocaoğlu, T., Bingöl, B. (2022). Futbol Sahalarında Hibrit Çim Kullanımının İrdelenmesi, Uluslararası

Doğu Anadolu Fen Mühendislik ve Tasarım Dergisi, 4(1), 53-66.

\section{Özet}

Spor müsabakaları gün geçtikçe daha profesyonel hale gelmiş ve buna bağlı olarak da halk arasında popülaritesini giderek artırmıştır. Spor müsabakaları içerisinde yer alan futbolda her zaman en ilgi çekici spor dallarından biri olmuştur. Artan ilgi, futbol sahalarının sayısını ve kullanım saatlerini de arttırmıştır. Futbol sahalarında tercih edilen doğal çim ise artan bu yoğun kullanımı karşılamakta zorlanmıştır. Yoğun kullanımın olduğu futbol sahalarında ve olumsuz hava şartlarının hakim olduğu bölgelerde karşılaşılan sorunlar sektördeki ilgilileri doğal çimden farklı alternatif arayışlarına yönlendirmiştir. Bu sorunlara çözüm bulmaya çalışan sentetik çim üreticileri de 1960‘lardan itibaren yeni nesil çimler üreterek bu sorunlara çözüm üretmeye çalışmışlardır. Hibrit çim ya da güçlendirilmiş doğal çim sistemi, 1989 yılından itibaren denenmeye başlanmış ve günümüzde doğal çim standartlarına en yakın olduğu düşünülen sistemdir. Oynanabilirlik ve performans standartlarının doğal çim saha standartlarını yansıtması, hibrit çimi öne çıkararak sistemin tercih edilebilirliğini artırmaktadır. Avrupa'da yaklaşık 20 yıldan fazladır tercih edilen ve ülkemizde de giderek yaygınlaşan hibrit çim futbol sahaları, doğal çimin yerini tamamen alamasa da gün geçtikçe yaygınlaşmaktadır. Bu çalışmada da hibrit çimin tanımı, futbol sahalarına tesis edilme yöntemleri ve doğal çim yüzeyli futbol sahaları ile karşılaştırılması yapılarak, hibrit çimin futbol sahalarındaki kullanılabilirliği incelenmiştir.

Anahtar Kelimeler: Hibrit çim, Yapay Çim, Futbol sahaları. 


\title{
Investigation of Hybrid Grass Use in Football Fields
}

\begin{abstract}
Sports competitions have become more professional day by day and accordingly, their popularity has increased among the people. Football, which is one of the sports competitions, has always been one of the most interesting sports branches. The increase in popularity has also increased the number of football fields and the hours of use. Natural grass, which is usually preferred in football fields, struggles in meeting this increased usage. Natural grass, which is preferred in football fields, has had difficulty in meeting this increasing use. The problems encountered in football fields with heavy use and in regions with adverse weather conditions have led the people in the sector to seek alternatives other than natural grass.Hybrid grass or reinforced natural grass system has been tried since 1989 and is considered to be the closest to natural grass standards today. The fact that playability and performance standards reflect the natural grass field standards, increases the preferability of the system by making the hybrid grass stand out. Hybrid grass football fields, which have been preferred in Europe for more than 20 years and become increasingly widespread in our country, are becoming more common day by day, although they cannot completely replace natural grass. In this study, the definition of hybrid grass, the methods of its installation on football fields, and the usability of hybrid grass in football fields were examined by comparing it with football fields with natural grass surface.
\end{abstract}

Keywords: Hybrid grass, Artificial grass, Football fields.

\section{Giriş}

Futbol sahaları gerek oyuncular gerekse de taraftarlar açısından son derece önemli olmasının yanı sıra, yayın haklarını bulunduran medya kuruluşları açısından da önem taşıyan unsurlardır. Futbol sahaları da oyuncular, top ve kale direkleri kadar maçın bir parçasıdır. Taraftarlar açısından stadyuma geldiklerinde önlerine çıkan yeşil halı görünümdeki saha, sahanın ıslak kalması için çalışan fiskiyeler ve saha görevlilerinin çalışmaları maçın ritüeli içerisinde yer alan hatıralardır (URL-1).

Spor müsabakaları gün geçtikçe daha profesyonel hale gelmiş ve buna bağlı olarak da halk arasında popülaritesini giderek artırmıştır. Artan bu ilgi yüzünden spor sahalarının da geliştirilmesi gerekmiştir. Spor müsabakaları içerisinde yer alan futbol her zaman en ilgi çekici spor dallarından biri olmuştur. Futbol sahaları zemininde ağırlıklı olarak doğal çim kullanılmaktadır. Sahanın yeşil renkte olması ve sahanın tamamının homojen olarak çim bitkisi ile kaplı olması ise son derece önemlidir. Olumsuz iklim şartlarının etkilediği bölgelerde ise doğal çimin bakımı kolay olmamaktadır. Ayrıca doğal çimin yıpranmaması için üzerinde oynanan futbol müsabakalarının sınırlı sayıda olması ve profesyonel bakım pratiklerinin uygulanması gerekmektedir. Özellikle halka açık, maç yükü fazla olan antrenman ve maç sahalarında bu ciddi bir problemdir.

Bu yüzden gelişen teknoloji sayesinde 1960'lardan itibaren sentetik (yapay) çim geliştirilmeye başlanmıştır. Sentetik çim her ne kadar sahalardaki oyun saatlerini artırmış ve bakım maliyetlerini düşürmüş olsa da sporcularda görülen yaralanmalar, kas ve eklem rahatsıllıkları, sürtünmeden oluşan cilt yanıkları, topun doğal çimde gösterdiği yuvarlanma ve sekme ile ilgili karakteristik özellikleri 
gösterememesi, kullanılan malzemenin sıcaklığı emmesi ve kötü kauçuk kokusu gibi nedenler kullanıcıları etkilemiştir. Kendi içinde bu sorunlara çözüm bulmaya çalışan sentetik çim üreticileri de yeni nesil çimler üreterek bu sorunların önüne geçmeye çalışmışlardır. Fakat 1990'ların sonunda UEFA (Avrupa Futbol Federasyonları Birliği) profesyonel seviyedeki oyunların sentetik çim sahalarda oynanmaması gerektiğine karar vermiş ve FIFA (Uluslararası Futbol Federasyonları Birliği)'de sentetik futbol sahaları için istenen oynanabilirlik ve performans standartlarının doğal çim saha standartlarını yansıtması gerektiğini açıkça ortaya koymuştur (SCC, 2018).

FIFA ve UEFA standartlarını karşılamaya çalışan üreticiler güçlendirilmiş doğal bir sistem üzerinde çalışmaya başlamışlardır. Hibrit futbol sahaların gelişimi ise Hollandalı Desso firmasının 1989 yılında doğal çimi stabilize etmek için sahanın alt tabanına enjekte/ankre (kalıcı sistem) edilen liflere sahip bir sistem geliştirmesi ile başlamıştır. GrassMaster adı altında ilk hibrit çim saha, Hollanda'daki Hertogenbosch'ta, De Vliert'te kurulmuştur. İngiltere'deki Huddersfield Town ise GrassMaster hibrit sistemini kuran ilk profesyonel stadyumdur. Wembley Stadyumu'ndaki GrassMaster kurulumları ve 2010 Dünya Kupası için Güney Afrika'daki iki sahanın (Peter Mokaba ve Mbombela) hibrit çim ile yapılması bu tekniği uluslararası düzeye taşımıştır. Brezilya'daki 2014 Dünya Kupası'nda ise Sao Paulo Arena'da gene hibrit çim sistemi uygulanmıştır (URL-2). 2015 yılından itibaren hibrit çimin temel tasarımına dayanan birçok farklı ürün geliştirilmiştir. Bu ürünler aynı zamanda farklı şekillerde de tesis edilebilmektedir. Artan ve tanınan ürünlerin kullanımı gün geçtikçe artış göstermiş, 2015 Rugby Dünya Kupası'nın 13 sahasından 9'unda ve Rusya'daki 2018 FIFA Dünya Kupası'nda kullanılan 12 stadın tamamında da hibrit çim kullanılmıştır (URL-3).

Hibrit çim sistemleri özellikle Avrupa'da yaklaşık 20 yıldan fazladır tercih edilmektedir. Her İngiliz Premier Ligi kulübünün bir hibrit yüzeyi vardır ve bunlar Avrupa takımları tarafından giderek daha fazla kullanılmaktadır. Barcelona, Real Madrid, Borussia Dortmund, Lechia Gdańsk, Club Brugge, Athletic De Bilbao, Derby Country, Feynoord Rotterdam, AFC Ajax, Olympique De Marseille ve Vitesse Arnhem gibi kulüpler hibrit çim devrime katılan takımlar arasındadır. Ülkemizde ise Ankara Eryaman, Atatürk Olimpiyat, Adana Koza, Beşiktaş Vodafone, Eyüp, Fatih Karagümrük Vefa, Fenerbahçe Ülker, Galatasaray Nef, Gaziantep Kalyon, Giresun Çotanak, Hatay Atatürk, Rize Çaykur Didi ve Trabzon Akyazı Medikal Park statlarında hibrit çim kullanılmaktadır. 
Hocaoğlu, T., ve Bingöl, B., Uluslararası Doğu Anadolu Fen Mühendislik ve Tasarım Dergisi / International Journal of Eastern Anatolia Science Engineering and Design (IJEASED)

(2022) 4(1): 53-66

\section{Hibrit Çim Tanımı ve Faydaları}

IFAB (Uluslararası Futbol Birliği Kurulu), Futbol Terimleri Sözlüğü’nde (2019) hibrit sistemin tanımı; "Güneş ışığı, su, hava sirkülasyonu ve biçme gerektiren bir oyun yüzeyi oluşturmak için yapay ve doğal malzemelerin bir kombinasyonu" şeklinde açıklanmıştır. UEFA, Saha Kalitesi Kılavuzu'nda (2018) ise çim takviye/güçlendirme sistemleri bölümünde hibrit sistemlerden bahsedilmektedir. Bu bölümde hibrit sistemden, "Doğal çimin oyun kalitesi açısından içerdiği faydaları, yapay malzemelerin pratik takviye edici ve mühendislik avantajlarıyla birleştirmeye çalışmaktadır” şeklinde bahsedilmektedir. Kısaca özetlemek gerekirse hibrit çim, hem doğal hem de yapay çim içeren, doğal çimi güçlendirerek dayanaklılığını artıran ve yıl boyunca yeşil bir görünüme sahip olmasını sağlayan bir üründür.
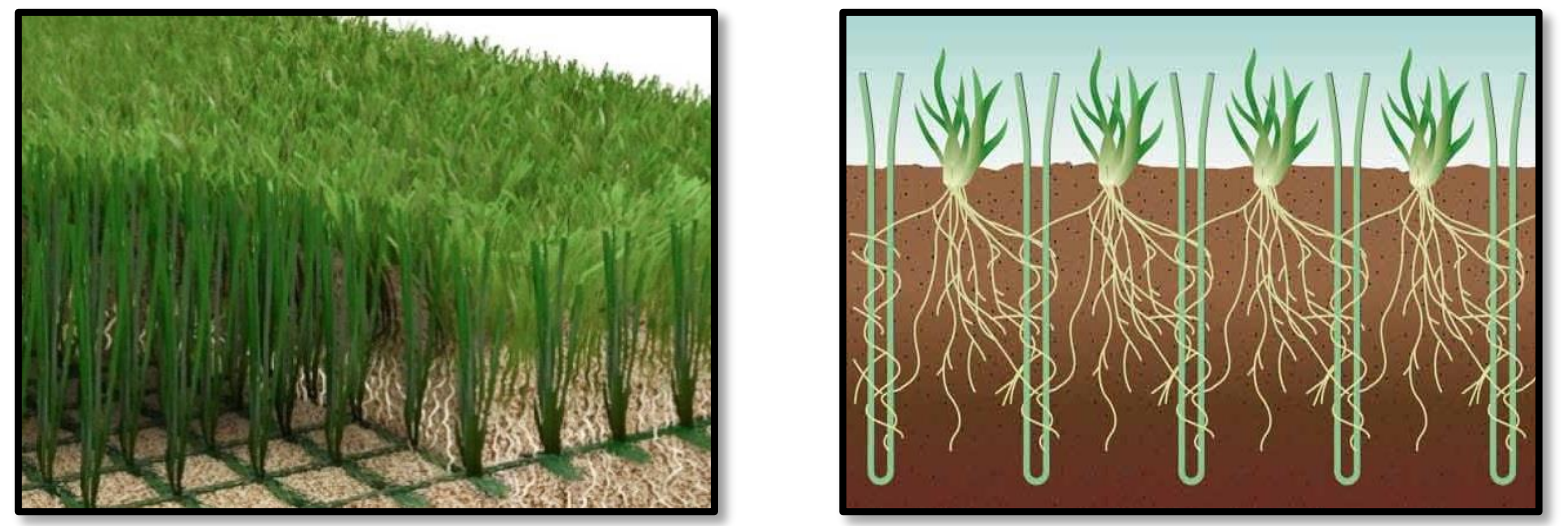

Şekil 1. Hibrit çim kesit görünümleri (URL-4, URL-5).

Hibrit çimin temel fikri, çimin gövdesi için korunaklı bir ortam sağlamak ve taban köklerinin uzun süre kullanılabileceği bir zemin yaratarak kökleri güçlendirmektir. Hibrit çim taban, bölgeye güçlendirici bir jeotekstil tabaka etkisi sağlayarak zemine destek oluşturur ve derin kök bölgesi tabakasının daha az sıkışmasını sağlar. Ayrıca hızlı rejenerasyon sağlayan çim kök sistemini de korur. Uzun vadede ise optimum koşulları sağlayarak alt tabakanın geçirgenliğini ve sağlıklı oksijen akışını sağlar (URL-6).

Hibrit çim sistemlerinin birçok faydası vardır. Hibrit çim, üst yüzeyi güçlendirir ve stabiliteyi artırır. Su geçirgenliğinin yüksek olması sebebi ile yüzeyin düzgünlüğünü artırır ve kötü hava koşullarında dahi maçın oynanmasını sağlar. Ayrıca oyun esnasında çimlerde oluşabilecek hasarlardan sahayı koruyarak çim boşluklarının ve sporcu sağlı̆̆ını etkileyecek derin yırtıkların da oluşmasını engeller.

Hibrit çim sistemin bir başka önemli faydası da doğal çimin yoğun kullanım nedeniyle aşındığı durumlarda dahi doğal çimde oynama hissini vermesi ve estetik olarak kısmen yeşil bir yüzey 
sağlamasıdır. Hibrit çim güçlü yapısı nedeni ile yılda 250 saat olan oyun saatini 1.000 saate kadar artırır. Bu sayede sahalarda daha fazla maç/antrenman yapılmasını sağladığı gibi başka aktivitelere de imkan tanıyarak kulüpler için ek gelir imkanı sağlar. Özellikle yeni tesis edilen çok amaçlı kapalı statlarda yetersiz hava akımı ve güneş ışığı nedeniyle kolayca yıpranan doğal çim, birçok bakım maliyetini de beraberinde getirmektedir. Doğal çim bakım maliyetleri düşünüldüğünde, sürdürülebilirliği ve düşük bakım maliyeti ile hibrit çim bir kez daha öne çıkarak sistemin tercih edilebilirliğini de artırmaktadır.

\section{Futbol Sahalarında Hibrit Çim Uygulamaları}

Hibrit çim sistemleri futbol sahalarında farklı yöntemlerle tesis edilse de tesis etmeden önce alanla ilgili bazı verilerin bilinmesi sistemin başarısını artıracaktır. Bu veriler aşağıdaki gibi siralanabilir.

- Alanın kullanım sıklığı.

- Alanın bulunduğu iklim kuşağı.

- Alanın güneşlenme süresi.

- Alanin taban toprak tipi.

- Alandaki taban suyu seviyesi ve kalitesi.

- Alanda gölge etkisinin belirlenerek, faydalı ışı periyodunun hesaplanması.

- Alandaki drenaj, sulama, isitma sistemi altyapisi.

- Alanda kullanılacak malzeme ve toprak analizleri.

- Alanın seviye ve tesviye tespiti.

- Alana tesis işlemi için gerekli ekipmanların bulunup bulunmadığı.

Futbol sahalarında hibrit çim tesisi üç yöntemle gerçekleştirilmektedir. Bunlar; Halı tabanlı yöntem, Kalıcı yöntem ve Karışım yöntemidir.

\section{a) Halı tabanlı yöntem (Mat-Carpet based)}

Polipropilen sentetik malzeme, doğal çimin derin ve köklü bir şekilde büyümesini sağlamak için geliştirilen, kısmen biyolojik olarak doğada dönüşebilen özel bir destek malzemesi üzerine örme ya da dokuma ile yerleştirilir. Bu arkalık taban bezi (keçe/pamuk lif/polipropilen) içerisinde yer alır ve 1zgara şeklindedir. Izgara malzeme ve taban bezi birbirine örülür. Bu arkalık aynı zamanda kolay ve kaliteli kurulum sağlar. Biyobozunur iplikler, iki ay içinde tamamen bozunarak, bitki köklerinin 
Hocaoğlu, T., ve Bingöl, B., Uluslararası Doğu Anadolu Fen Mühendislik ve Tasarım Dergisi / International Journal of Eastern Anatolia Science Engineering and Design (IJEASED)

(2022) 4(1): 53-66

büyüdüğü, nem ve besinlerin aktığı büyük tek tip boşluklardan oluşan bir matris oluşturur (URL-7). Halı tabanlı yöntemde \% 90-92 doğal çim kullanılırken, \% 10-8 sentetik elyaf kullanılır (URL-8) (Şekil 2). Yöntem yeni saha tesisinde kullanıldığı gibi mevcut sahalarda da yüzeyin kaldırılması ve alt toprağın hazırlanıp tesviye edilmesinden sonra kullanılabilir. Ayrıca halı tabanlı yöntem, hazır çim tesislerinde üretilip, kalın ve uzun rulolar halinde de alana serilebilir (Ser ve oyna/Lay and play).
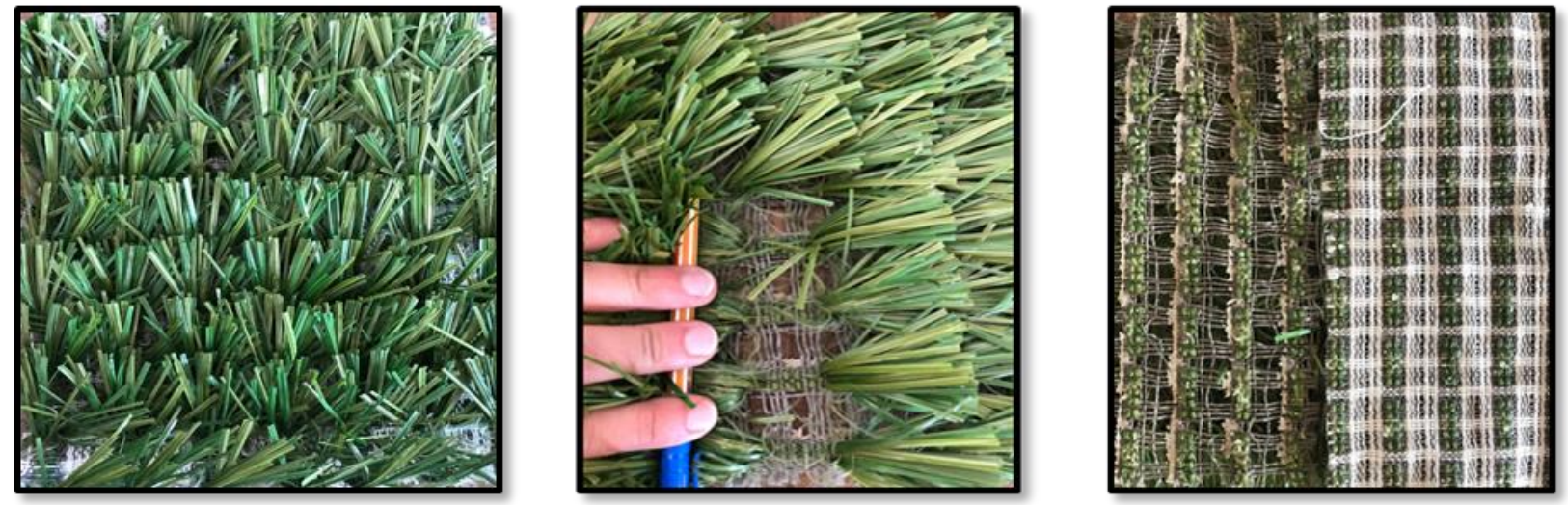

Şekil 2. Halı tabanlı sistem örneği (XtraGrass hibrit çim)

Ön hazırlık işlemlerinin tamamlanmasından ardından halı tabanlı sistem, uygulanacak alana gerekli ekipmanların yardımı ile halı şeklinde serilir. Serme işlemi tamamlandıktan sonra organik maddeleri de içeren yetiştirme/çimlenme ortamını sağlayacak kumlama işlemine geçilir. Çim bitkisine destek olacak hibrit lifleri dikleştirmek için alana $30 \mathrm{~mm}$ kum serilir. Kumlama işleminin ardından homojen dağılımı sağlamak için serilen kum, 3 turdan az olmamak suretiyle değişik yönlerden firçalama işlemine tabi tutulur. Daha sonra bölgenin iklim şartlarına uygun çim tohumu ile ekim işlemi gerçekleştirilir. Başlangıç gübrelemesi ile ekim işlemi sonlandırılır ve sulama başlatılır. $\mathrm{Bu}$ işlemde çim tohumları, halı tabanını geçerek kum alt tabakasına rahatça kök atarken, çim bitkisi de liflere tutunarak büyür. Bu sayede de dayanıklı ve sık dokulu bir saha zemini elde edilir (Şekil 3). 


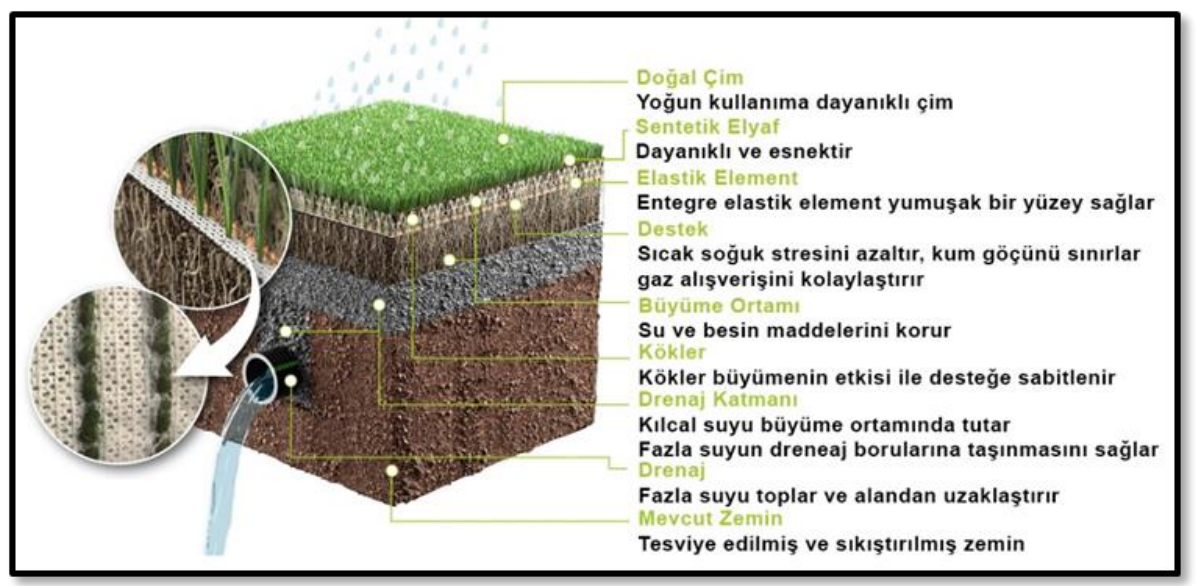

Şekil 3. Halı tabanlı sistem kesit görünümü (URL-9)

Halı tabanlı hibrit yönteminin birçok faydası vardır. Yüzey tabakasının geçirgenliği ve oksijen akışını sağlayarak doğal çim için optimum koşulları sağlar ve ideal hava-su toprak dengesini oluşturur. Oyun yükünün ağır olduğu alanlarda düzlük ve stabilite açısından alanın güvenilirliğini artırır ve güçlü yapısı sayesinde boşluklara rastlanmaz. Halı tabanı, jeotekstil görevi görerek alt kök bölgesi katmanında daha az sıkışmaya neden olur ve hızlı rejenerasyon sağlayan çim kök sisteminin korunması sağlar. Ayrıca sentetik liflerin yeşil görünümü ile saha estetiğine renk katkısında bulunur.

Halı tabanlı hibrit çim sisteminde uygulama yapılırken tüm gerekli ekipmanlar mutlaka kullanılmalıdır. Uygulama esnasında ek yerleri mutlaka üst üste bindirilmeli ve dikerek veya yapıştırılarak birbirine sabitlenmelidir. Bu işlemde saha, tesis edilme sezonuna bağlı olarak 9-10 haftalık bir süreç sonrası kullanıma hazır hale gelmektedir (Şekil 4).
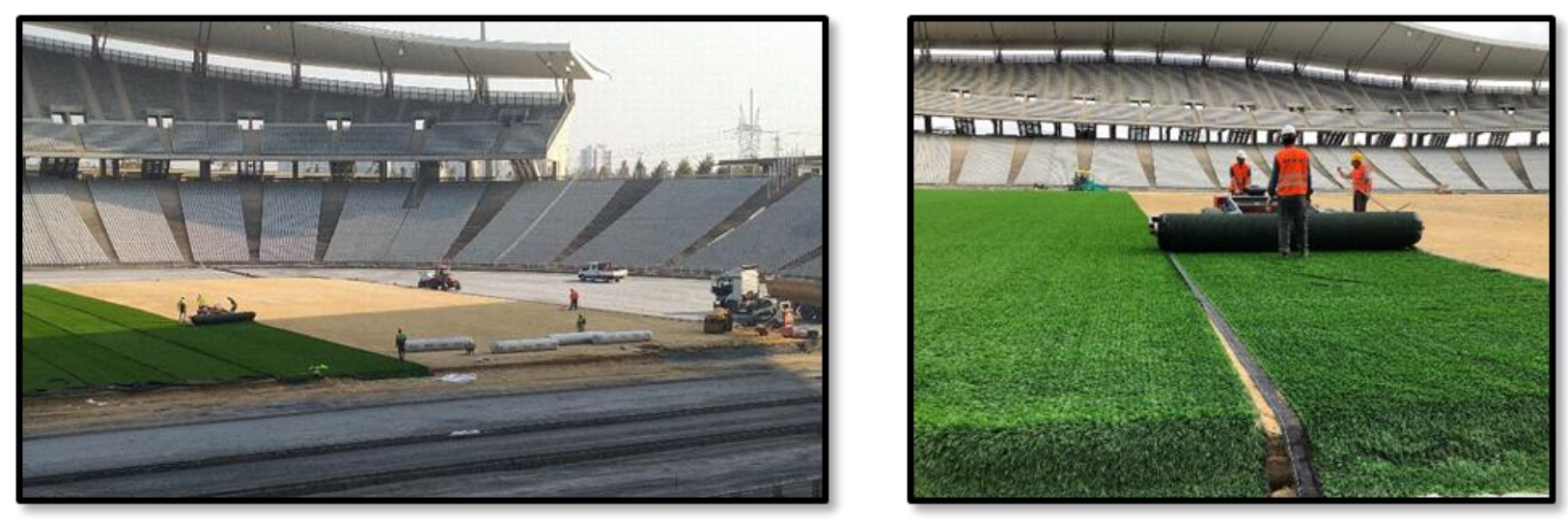

Şekil 4. Atatürk Olimpiyat Stadı Halı tabanlı sistem uygulaması (Hatko hibrit çim)

Halı tabanlı yöntemin avantaj ve dezavantajları ise Tablo 1'de belirtildiği gibi özetlenebilir. 
Hocaoğlu, T., ve Bingöl, B., Uluslararası Doğu Anadolu Fen Mühendislik ve Tasarım Dergisi / International Journal of Eastern Anatolia Science Engineering and Design (IJEASED)

(2022) 4(1): 53-66

Tablo 1. Halı tabanlı yönteminin avantaj ve dezavantajları

\begin{tabular}{ll}
\hline \multicolumn{1}{c}{ Avantajları } & \multicolumn{1}{c}{ Dezavantajları } \\
\hline Yöntem rulo çim olarak uygulanırsa hızlı kurulum. & Uzun süren kurulum. \\
Yüzey ve kök bölgesinin stabilitesini arttıır. & Kök bölgesinin hızlı kuruması. \\
Oyun saatlerini artırır. & $3-5$ yıl ömür. \\
Saha estetiğine renk katkısında bulunur. & Saha yüzeyinde sertlik. \\
Çim boşluklarına rastlanmaz. & Maç sezonu sonrası yılda bir kez tadilat. \\
Sahanın çok işlevli kullanımını sağlar. & Onarım maliyetlidir. \\
Yöntem sadece sahanın yoğun kullanıldı̆̆ı bölgelerde de & Sistemi kaldırmak ve geri dönüşüm maliyetlidir. \\
kullanılabilir. & \\
\hline
\end{tabular}

\section{b) Kalıcı yöntem (Stitched)}

$\mathrm{Bu}$ yöntemde, doğal çim ile daha önceden tesis edilmiş ya da yeni yapılmış saha üzerine lazerli hassas kontrol imkanına sahip, bilgisayar ile yönlendirilebilen elektrikli makinaların kullanımı ile polipropilen olarak adlandırılan sentetik malzeme, yüzeyin yaklaşık 9-18 cm. kadar olan kısmına enjekte/ankre edilerek gerçekleştirilmektedir (URL-10) (Şekil 5). Bu yöntemde yüzeye enjekte edilen sentetik elyaflar herhangi bir desteğe bağlanmadan durur ve elyaflar arasında doğal çim büyür. Kalıcı yöntem \% 95 doğal çim, \% 5 sentetik çim içerir (URL-8).

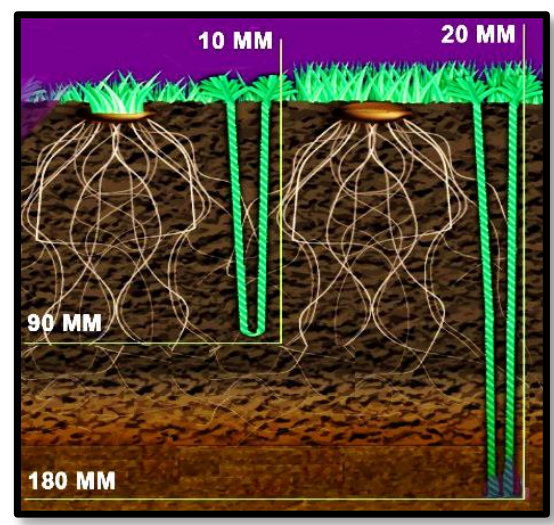

Şekil 5. Kalıcı yöntem kesit görünümü (URL-10)

Kalıcı yöntemde doğal çimin kökleri yapay malzeme ile iç içedir. Bu yöntem, alan yüzeyinin sabitlenmesine ve eşit oranda bir kaplama elde edilmesine olanak sağlar. Bir futbol sahasında enjeksiyon işlemi ise $2 \times 2 \mathrm{~cm}$. ölçülerinde yapılır ve bu işlemde yaklaşık 20.000.000 sentetik lif kullanılır (URL-11). Günümüzde farklı hibrit çim üreticilerinin bu işlem için farklı makinaları bulunmakla birlikte izlenilen yöntem ise aynıdır (Şekil 6, Şekil-7). 

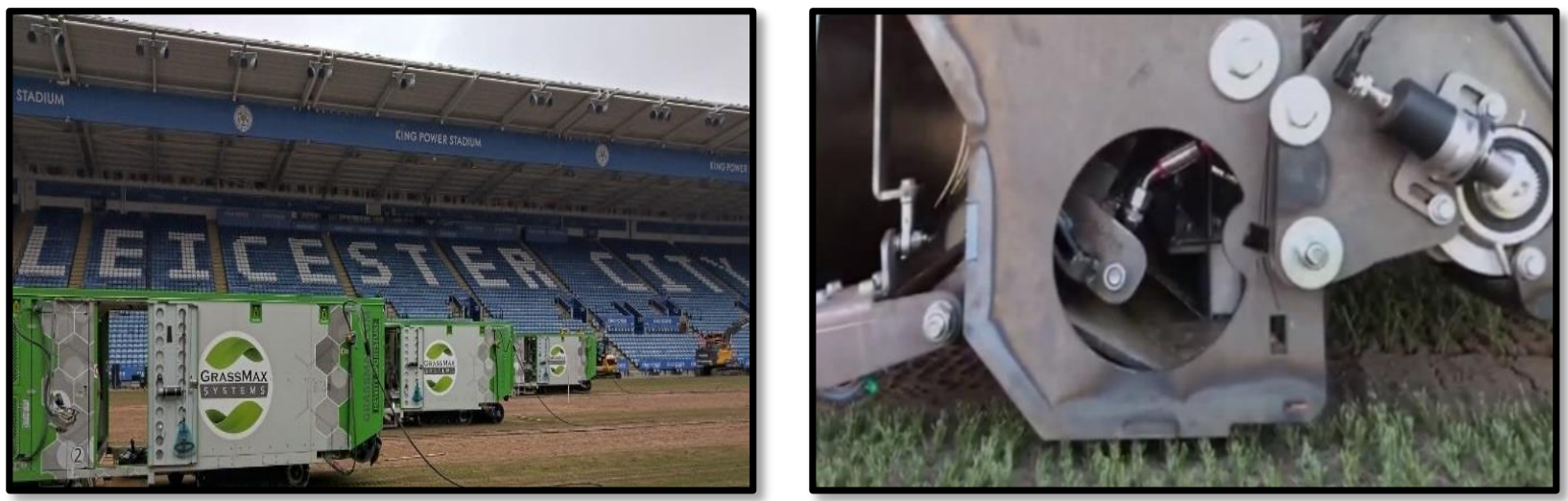

Şekil 6. Kalıcı sistem yönteminin futbol sahasına uygulanması (GrassMaster) (URL-12, URL-11)
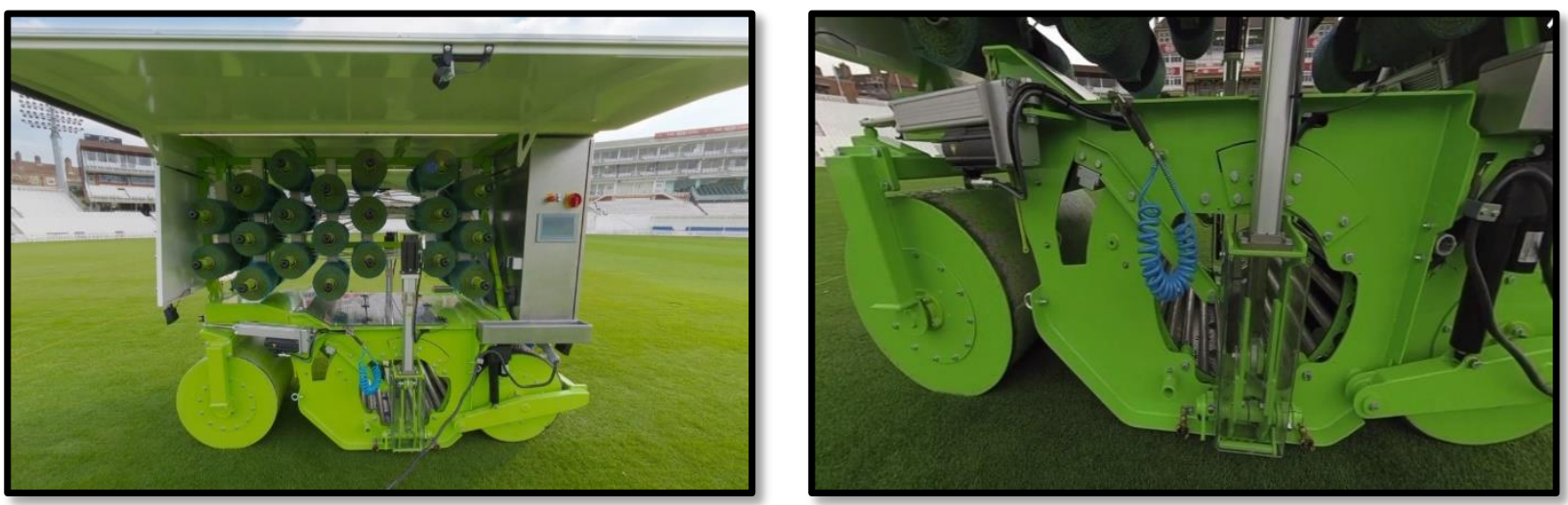

Şekil 7. Kalıcı sistem yönteminin futbol sahasına uygulanması (XtraGrass) (URL-13)

Sentetik elyafların kum bazlı çim sahaya dikilmesi, suyun yüzeyden hızla boşalmasını sağlar. Bu sayede maç iptallerinin önüne geçilir. Kök yüzeyinin üzerinde yükselen lifler, UEFA veya FIFA tarafından belirtilen standart biçim yüksekliklerinin altında ve sabit kalır. Çimin biçilmesi ise sentetik elyaflara zarar vermez (URL-12). Kalıcı yöntemin avantaj ve dezavantajları ise Tablo 2'de belirtildiği gibi özetlenebilir.

Tablo 2. Kalıcı sistemin avantaj ve dezavantajları

\begin{tabular}{ll}
\hline \multicolumn{1}{c}{ Avantajları } & \multicolumn{1}{c}{ Dezavantajları } \\
\hline Zemini kaldırmadan mevcut alanda kurulum. & Liflerin köklerle sabitlenememesi. \\
Hızlı kurulum (7 gün). & Kurulum sırasında altyapı sistemlerine olası hasar. \\
Yüzey ve kök bölgesinin stabilitesini arttırır. & Zor onarım. \\
Oyun saatlerini artırır. & Saha yüzeyinde sertlik. \\
Saha estetiğine renk katkısında bulunur. & Maç sezonu sonrası yılda bir kez tadilat. \\
Çim boşluklarına rastlanmaz. & Yüksek yapım maliyeti. \\
8-10 yı̈ ömür. & Sistemi kaldırmak ve geri dönüşüm maliyetlidir. \\
\hline
\end{tabular}


Hocaoğlu, T., ve Bingöl, B., Uluslararası Doğu Anadolu Fen Mühendislik ve Tasarım Dergisi / International Journal of Eastern Anatolia Science Engineering and Design (IJEASED)

(2022) 4(1): 53-66

\section{c) Karışım yöntemi (Fibresand, Fiberlastic, AirFibr)}

Bu hibrit çim yönteminde ise mikro elyaf karışımı kullanılır. Aslında daha çok görünmeyen kök bölgesinin güçlendirme işlemidir. Çünkü lifler yüzeyde yer almadığından sahanın yeşil görünümüne ve yüzeydeki yıpranmalara katkı sunmaz. Mikro sentetik elyaf, kök bölgesinde kullanılacak malzeme ile homojen olarak karıştırılarak karışım elde edilir. Daha sonra bu karışım yüzeye dağıtılır ve içine bor minerali eklenir (URL-14). Bu işlemi tohum ekimi takip eder. Ekim sonrasında doğal çim sahalar gibi tamamen aynı şekilde yönetilir (Şekil 8).

AirFibr yönteminde de benzer şekilde silika/silis kumu, sentetik mikrofiber ve granül mantar karıştırılarak alt zeminde kullanılır ve diğer yöntemlerle benzer şekilde uygulanır (URL-15).

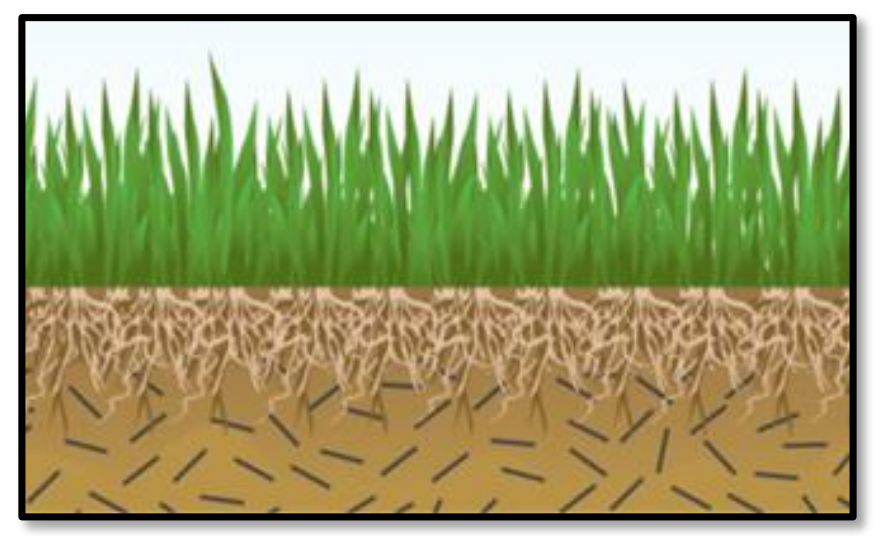

Şekil 8. Elyaf karışım yöntemi kesit görünümü (URL-16)

$\mathrm{Bu}$ yöntemde kullanılacak sentetik elyafların doğru seçimi ve karışımdaki yüzdesi son derece önemlidir. Elyaflar ne kadar güçlü ve iyiyse, yüzey ve stabilizasyonu ve oynama özellikleri de o kadar güçlü olur. Kum, kök bölgesine gerekli serbestliği verir. Çürümeye karşı dayanıklı lifler, hava ve suyu daha derinlere ileterek sağlıklı çimlerin büyümesine yardımcı olur ve böylece daha derin ve daha güçlü kök gelişimini teşvik eder. Serbest drenajlı, dengeli ve tutarlı bir oyun yüzeyi sağlar (URL17).

Çim, ıslak koşullarda yoğun kullanıma maruz kaldığında bile kramponlardan kaynaklanan sıkışmaya ve yüzey hasarına karşı daha dayanıklı hale gelir (URL-17). Yoğun oyun yükünün görüldüğü alanlar için son derece uygun olup \% 100 doğal çimde oynama avantajı sağlar (Şekil 9). 

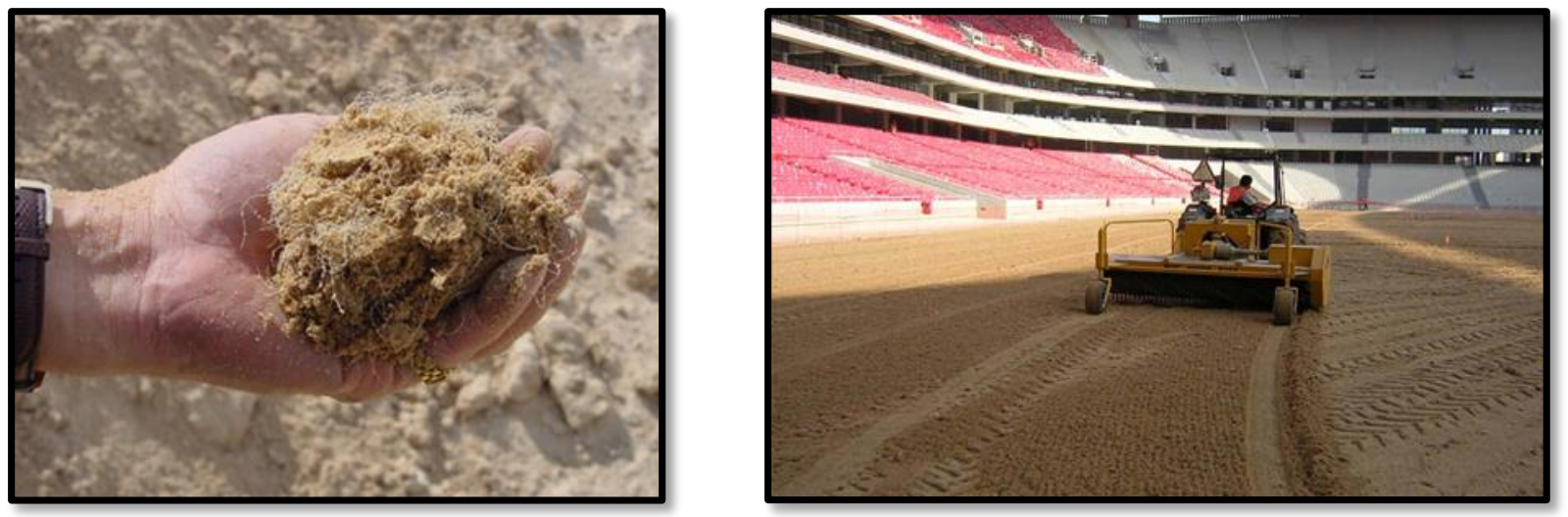

Şekil 9. Karışım yönteminin futbol sahalarında uygulanması (URL-18, URL-19)

Karışım yöntemin avantaj ve dezavantajları ise Tablo 3'de belirtildiği gibi özetlenebilir.

Tablo 3. Karışım yönteminin avantaj ve dezavantajları

\begin{tabular}{ll}
\hline \multicolumn{1}{c}{ Avantajları } & \multicolumn{1}{c}{ Dezavantajları } \\
\hline Oyun saatlerini artırır. & Dikey stabilizasyon eksikliği. \\
Gelişmiş kök sistemi sağlar. & Saha estetiğine renk katkısında bulunmaz. \\
Drenaj özelliklerini arttırır. & Çim boşluklarına rastlanır. \\
Standart bakım ve onarım. & Özel tesisat, ekipman ve ataşman kullanımı nedeniyle \\
& artan fiyatlar. \\
& Sistemi kaldırmak ve geri dönüşüm maliyetlidir. \\
\hline
\end{tabular}

\section{Hibrit Çimin Doğal Çim İle Karşılaştırılması}

Sağlık, maliyetler ve oynanabilirlik söz konusu olduğunda hem doğal çimin hem de hibrit çimin kendilerine göre artıları ve eksileri vardır. Bu noktada kulüpler seçim yaparken kendi şartlarını da gözden geçirmeli ve tüm bu hesaplamaları yapmalıdır. Doğal çim yüzeylerin uzun süredir kullanılır olması ve bilinirliliği yanında hibrit çimin de getirdiği avantajlar dikkate alınmalı ve sahanın kullanım amaçları da göz önünde bulundurularak seçim yapılmalıdır. Doğal çim ve hibrit çim arasındaki değerlendirme ise Tablo 4'de belirtildiği gibi özetlenebilir. 
Hocaoğlu, T., ve Bingöl, B., Uluslararası Doğu Anadolu Fen Mühendislik ve Tasarım Dergisi / International Journal of Eastern Anatolia Science Engineering and Design (IJEASED)

(2022) 4(1): 53-66

Tablo 4. Doğal çim ve hibrit çimin karşılaştırılması

\begin{tabular}{|c|c|}
\hline Doğal Çim & Hibrit Çim \\
\hline Alt zemin katmanı önemlidir. & Farklı alt zeminlere uygulanabilir. \\
\hline Alan yüzeyi daha hızlı deforme olur. & Alan yüzeyi çabuk deforme olmaz. \\
\hline Rejenerasyon süresi uzundur. & Rejenerasyon süresi kısadır. \\
\hline Doğal çim kökleri toprak altında daha esnektir. & Doğal çim kökleri toprak altında daha serttir. \\
\hline Çok bakım ister. & Az bakım ister. \\
\hline Sürdürülebilirlik süresi kısadır. & Sürdürülebilirlik süresi uzundur. \\
\hline $\begin{array}{l}\text { Yipranma olduğunda saha estetiğine renk katkısında } \\
\text { bulunmaz. }\end{array}$ & $\begin{array}{l}\text { Yıpranma olduğunda saha estetiğine renk katkısında } \\
\text { bulunur. }\end{array}$ \\
\hline Çim boşlukları ve yırtılma gözlemlenmesi. & Çim boşlukları oluşmaz ve yırtıklar az seviyededir. \\
\hline Yapım maliyeti düşüktür. & Yapım maliyeti yüksektir. \\
\hline Bakım maliyeti yüksektir. & Bakım maliyeti düşüktür. \\
\hline \multirow[t]{2}{*}{ Doğal } & Yarı doğal ve yarı yapay liflerden üretilir. \\
\hline & Sistemi kaldırmak ve geri dönüşüm maliyetlidir. \\
\hline
\end{tabular}

\section{Sonuçlar ve Öneriler}

Ülkemizde de çokça sevilen futbol, dünyada en fazla ilgi duyulan spordur. Her kıtada, her ülkede ve birçok farklı seviyede oynanır. Müsabakaların gerçekleştirildiği futbol sahalarının zemini ise müsabaka talimatlarının izin verdiği doğal ve yapay malzemelerin bir arada kullanılması (hibrit sistem) ile; tamamen doğal veya eğer müsabaka talimatları izin verirse, tamamen yapay olabilir (IFAB, 2021)

Tüm dünyada olduğu gibi son dönemde ülkemizde de futbol sahalarının zemininde hibrit çim yöntemi sıklıkla tercih edilmektedir. Çalışmada detaylı olarak incelenen bu yöntem, olumsuz iklim koşullarının görüldüğü bölgelerde, özellikle bakım aşamasında ve yoğun oyun yükünün bulunduğu sahalarda doğal çime oranla bir adım öne çıkmaktadır. Ayrıca güçlü yapısı ile çim boşluklarının oluşmasının önüne geçmekte ve saha estetiğine renk katkısında bulunmaktadır. Hibrit çim ekonomik açıdan daha maliyetli olmasına karşın bakım masrafları açısından ise daha düşüktür. Hangi yöntemde tesis edilirse edilsin yerel federasyonun, UEFA ve FIFA talimatlarında bulunan doğal çim yüzeyli futbol saha kalite standartlarına uyması gerekmektedir. Bunun sağlanması için periyodik olarak "çim test aletleri ile kayıtlar tutulmakta ve özellikle büyük organizasyonlardan önce sahalar takibe alınmaktadır. Dolayısıyla buradaki en önemli nokta hibrit çim yönteminin uzunca bir süredir kullanılan ve tüm yönleriyle bilinen doğal çimin standartlarını karşılayıp karşılayamadığıdır.

Doğal çim yüzeyli sahalar uzun yıllardır oyun sahalarında kullanıldığı için tüm karakteristik özellikleri yapımdan bakıma kadar detaylı şekilde bilinmektedir. Oysa hibrit çim yöntemi son yıllarda 
yaygınlaştığından sonuçları henüz tam olarak ortaya çıkmamıştır. Bu noktada hibrit çim sahalarının oyun karakteristiklerine, oyun kalitesine ve sporcu sağlığı üzerine etkilerinin bilimsel olarak daha detaylı çalışılması gereklidir. Bu yöntemle tesis edilmiş sahalarda kullanılan bakım makineleri doğal çim bakımı için geliştirilmiş makineler olup hibrit bakımı için makinelerin de geliştirilmesi gerekmektedir. Ayrıca bu uygulamanın tercih edildiği sahalarda yapımdan sonra bakım aşamasında da görev alan kişilerin bu yeni sistemin bakım ve mekanizasyon ihtiyaçları konusunda bilgilendirilmesi gerekmektedir.

Günümüzde hızla gelişen ve değişen teknoloji, artan oyuncu performansı elbette futbol sahalarındaki standartları değiştirecek, geliştirecek ve yeni standartları belirleyecektir. Önemli olan her yeni teknolojinin tüm dünyada sevilen ve izlenen bu spor dalının seyir zevkini, oyun kalitesini ve sporcuların sağlığını olumlu yönde etkilemesidir.

\section{Yazarların Katkısı}

Çalışmada her iki yazar da eşit oranda katkı sunmuştur.

\section{Çıkar Çatışması Beyanı}

Yazarlar arasında herhangi bir çıkar çatışması bulunmamaktadır.

\section{Araştırma ve Yayın Etiği Beyanı}

Yapılan çalışmada, araştırma ve yayın etiğine uyulmuştur.

\section{Kaynaklar}

IFAB, (2018). Laws of the game 18/19, International Football Association Board, Zurich, Switzerland. IFAB, (2021). Laws of the game 21/22, International Football Association Board, Zurich, Switzerland.

SCC, (2018). The Smart Guide to Synthetic Football Fields Including Hybrid Technology, Smart Connection Consultancy, South Melbourne, Victoria, Australia.

UEFA, (2018). Pitch Quality Guidelines, Natural turf pitch management, Union of European Football Associations, Nyon 2, Switzerland.

URL-1: https://www.football-stadiums.co.uk/articles/football-pitch-grass-types/, (Erişim Tarihi: 15 Kasim 2021).

URL-2: https://www.grassmastersolutions.com/en/about-us, (Erişim Tarihi: 10 Kasım 2021).

URL-3: https://www.stad-en-groen.nl/article/18366/the-road-to-a-fifa-world-cup-pitch, (Erişim Tarihi: 09 Kasim 2021).

URL-4: https://www.hgturfgroup.com.au/products/hero-hybrid-grass, (Erişim Tarihi: 07 Kasım 2021).

URL-5: https://www.plastix-world.com/milan\%E2\% $80 \%$ A2meazza-stadium-hybrid-grass-wins-on-footballfield/, (Erişim Tarihi: 22 Kasım 2021).

URL-6: https://avengrass.com/hybrid-grass/, (Erişim Tarihi: 03 Kasım 2021).

URL-7: https://www.xtragrass-hybrid-turf.com/hybrid-turf-system/, (Erişim Tarihi: 05 Kasım 2021).

URL-8: https://www.sispitches.com/hybrid-grass-guide, (Erişim Tarihi: 06 Kasım 2021).

URL-9: https://powergrasshybrid.com/contents/2/group/, (Erişim Tarihi: 13 Kasım 2021).

URL-10: https://www.sispitches.com/products/sisgrass-lite/, (Erişim Tarihi: 10 Kasım 2021).

URL-11: https://www.grassmastersolutions.com/en/grassmaster-overview, (Erişim Tarihi: 10 Kasım 2021). 
Hocaoğlu, T., ve Bingöl, B., Uluslararası Doğu Anadolu Fen Mühendislik ve Tasarım Dergisi / International Journal of Eastern Anatolia Science Engineering and Design (IJEASED)

(2022) 4(1): 53-66

URL-12: https://www.grassmax.com/hybrid-stitching, (Erişim Tarihi: 22 Ekim 2021).

URL-13: https://www.sispitches.com/products/sisgrass-universal/, (Erişim Tarihi: 12 Kasım 2021).

URL-14: http://engobel.by/en/blog/gibridnyi-gazon, (Erişim Tarihi: 12 Kasim 2021).

URL-15: http://www.airfibr.com/en/, (Erişim Tarihi: 11 Kasım 2021).

URL-16: https://countyturf.co.uk/, (Erişim Tarihi: 13 Kasım 2021).

URL-17: http://www.fibresand.com/products/fibreturf/, (Erişim Tarihi: 12 Kasım 2021).

URL-18: https://www.externalworksindex.co.uk/entry/127181/Fibresand-International/Fibresand-rootzonereinforcement/, (Erişim Tarihi: 22 Kasım 2021).

URL-19: http://www.fibresand.com/sport/, (Erişim Tarihi: 05 Kasım 2021). 